\title{
The Effects of Gentrification on the Elderly: A Case Study in the City of Cáceres
}

\author{
Lidia Domínguez-Parraga \\ Department of Sociology, University of Extremadura, Plaza de Caldereros, s/n., 10003 Cáceres, Spain; \\ lgdominguezparraga@unex.es
}

Received: 6 August 2020; Accepted: 1 September 2020; Published: 7 September 2020

\begin{abstract}
This study aims to analyze the consequences of the gentrification process as a result of tourism on the elderly inhabitants. Firstly, the concept of gentrification is reviewed, a process that is no longer exclusive to large cities but has spread to smaller and lesser-known municipalities. A clear example of this type of new tourist destination is the city of Cáceres, a World Heritage medium-sized city where tourism is the basis of its economy. The research considers gentrification in medium-sized cities and its effect on active aging. Based on a qualitative methodological approach, a total of 32 in-depth interviews were conducted and analyzed to compare two neighborhoods-one gentrified and one not. The results show a remarkable disparity in the residents' perceptions of their environment and their city. The findings suggest adverse effects on the quality of aging due to the gentrification process, such as family dependency, social-space disconnection, and a generally pessimistic image of the neighborhood. Consequently, the impact of tourism negatively affects the gentrified neighborhood inhabitants' psychological, social, and emotional well-being.
\end{abstract}

Keywords: gentrification; neighborhood; qualitative analysis; aging; older people

\section{Introduction}

Spain is one of the main tourist destinations in the world, which is evident by its economy. In 2018, according to data from the Tourism Satellite Account in Spain (CSTE) (INE 2019), tourism accounted for more than $12 \%$ of GDP and generated $12.7 \%$ of total employment in the country. Nevertheless, the impact of tourism goes beyond the economic impact, having meaningful effects on society. The consequences of tourism on the population of a city have been widely studied in recent years, as well as the effects of so-called "gentrification." However, most studies on gentrification have been carried out in metropolises. This research aims to mitigate this gap by conducting an investigation on gentrification in a tourist destination of a medium-sized city-Cáceres, Spain. A different approach is proposed by selecting older people as the research subjects, with the reason being that this population segment is not frequently studied in the currently available literature on the gentrification process (Petrovic 2008).

\section{Gentrification Process}

Ruth Glass's definition (1964) can be considered as one of the first definitions of gentrification. The definition of the gentrification process of an area is the remodeling or revitalization of an urban space that results in the displacement of low-income people who previously lived there (Glass 1964). A more modern definition can be found in UN-Habitat's Leading Change: Delivering the New Urban Agenda through Urban and Territorial Planning: "The process of social change that takes place in a neighborhood, often previously occupied by low-income residents, as more affluent people move in" (UN-Habitat 2018, p. 5). 
However, since the first approach to studying the concept of gentrification by Glass (1964), new factors have been incorporated to explain its effects more broadly, such as consumption (Zukin 1990) or tourism (Hiernaux and González 2014). Consequently, expressing the gentrification process in a single definition might not be convenient, nor would it be advantageous for its analysis from a scientific perspective. Indeed, for authors such as Bounds and Morris (2006), it is considered as counterproductive. The variables involved in this process are diverse, so delimiting them to a pre-defined group would not allow for a comprehensive knowledge and understanding of gentrification in all its complexity.

In this study, tourism is the principal agent of the gentrification process, since it is currently one of the crucial catalysts of gentrification in numerous cities. According to Harvey (2008), cities have become the new setting for social struggles. Previously, demands focused on improving workers' rights and were located in factories and industries. However, they have now spread to all public spaces. In this way, social struggles are diversified, and the objectives of social movements are broader, with a focus on improving city life. The author David Harvey proposed the idea of "accumulation by dispossession," developed from the Marxist notion of "primitive accumulation" (Harvey 2004). Thus, social movements fight against dispossession by trying to recover the common goods of cities, which by right belong to them. Through "accumulation by dispossession," it is considered that the common goods have been snatched by the capitalist system, which expropriates the inhabitants' common spaces to develop a series of activities and experiences that it sells to tourists. As a result, gentrification has generated a new class struggle. The confrontation is centered between the regular resident who strives to continue living in the same urban space against the middle-to-upper class and the new actor-the tourist (Janoschka 2018). The changes created by this novel situation are not limited to the physical transformations of the structures in the neighborhoods, nor to the corresponding politics to increase the city's economy. They have a substantial impact on how traditional residents produce, interact, and live in the symbolic space (Hiernaux and González 2014). As Lefebvre explained in Le droit à la ville (Lefebvre 1968), citizens are losing importance in the urban scene, which is not designed based on the citizens' needs but according to profit demands, leaving the right to the city in the hands of capitalism.

The increase in tourism in Spain has contributed to the gentrification of several areas of the country. For Janoschka (2018), Spanish gentrification can be divided into five categories according to its characteristics. Those that are related to the city of Cáceres, the object of this investigation, will be highlighted:

- Gentrification by tourism dispossession. Appropriation by tourism of the real estate market in addition to the common areas.

- Gentrification by commercial and symbolic exclusion. Policies focused on attracting and creating products for tourism imply a modification of the urban environment, which is not typically related to the needs of the original citizens, making it impossible for residents to relate to the new local commerce.

- Gentrification everywhere. This category refers to the dispersion of gentrification in Spain that has moved beyond the large cities to reach less accessible regions that had not been considered previously (Janoschka et al. 2014).

Consequently, gentrification implies a change in the relationship and interaction among tourists, new residents, establishments, and shared spaces. That is, it means a change in the interactions between traditional inhabitants and their physical and symbolic environment. This way, the negative effect of the gentrification process manifests itself as increased rents and the destruction of small commerce, which cannot compete with the large multinationals or exclusive establishments that arrive to respond to the new upper-middle-class and tourism needs (Romero Renau and Martin 2015). In turn, traditional customers are forced to move to other areas to make their purchases so that "they are not physically excluded but symbolically kept at a distance" (Hiernaux and González 2014, p. 64). At this point, traditional residents will have lost all their rights to space, and consequently, the rights to the city where they live. 


\section{Gentrification and Aging}

Henig (1984) analyzed the gentrification process in the 1970s and its effects in seven major cities of the United States. The gentrification process was more likely to occur in those neighborhoods with a higher percentage of elderly people and was less likely to occur in those neighborhoods with a higher rate of young people. Harvey (2008) argued that the gentrification process causes the older population in these areas to decrease significantly. It forces older residents to move to other neighborhoods because they cannot afford to continue living in the same house. Atkinson (2000) reached very similar conclusions in a study evaluating London's gentrification and the consequences and characteristics of the displacements produced by this process in the great metropolis.

The imposed displacement is widespread and is part of gentrification's consequences; however, its effects are not equitable. Most traditional residents are forced to leave their homes and move to new neighborhoods where the standard of living is more in line with their social status and economic level. In the case of older people, this change is even more complex. Those who do manage to move-not all of them can, since, for example, some are not renting but own their homes-can have emotional, social, physical, and psychological impacts due to the effects of the change (Atkinson 2000; Henig 1984; Petrovic 2008).

On the other hand, not all environments are appropriate for an aging population. If active aging ${ }^{1}$ is considered, as the paradigm of healthy aging ${ }^{2}$, the environment must have a series of characteristics both in the private sphere-the home-and in the public sphere-the urban environment-that help older people to be independent in all aspects, including their active participation in the society of which they form part (Brusilovsky 2016). For this population segment, it will be just as essential to find a new place that suits their economic needs as one that makes it easier for them to live independently, i.e., one in which essential services, such as shops, leisure and meeting centers, or health centers, are available to meet the daily physical and emotional needs for successful aging (Domínguez-Párraga 2019a).

As mentioned, two other reasons can also condition mobility in different zones of the city-the emotional and psychological relationship with the home; and the economic problem of assuming a rent or buying a new home. Consequently, these traditional residents and seniors must remain in their now gentrified neighborhood. They find themselves trapped in an environment that no longer belongs to them or that they feel "alien" to. The creation of new businesses that replace the old ones means that the relationships established in the past disappear and this forces the elderly to move outside their neighborhood to obtain basic foodstuffs, such as bread, at a price in keeping with their standard of living (Petrovic 2008. Although this action does not seem to be a significant problem for those of a mature age, for the elderly it can be an inconvenience, given the physical and mobility difficulties inherent to the age group. A situation where the simplest daily activities require travelling a long distance or a great effort may decrease the number of tasks accomplished, leading to less independence and increased hours at home. The consequences of these possible situations lead to psychological illnesses such as depression or aggravation of mobility problems (Almeida 2014). In short, they turn senior residents into prisoners in their own homes, in a social environment that is more concerned with responding to new residents' needs than with preserving old residents and their ways of life (Petrovic 2008).

1 The World Health Organization (WHO) formalized the term active aging at the institutional level as "the process of optimizing opportunities for health, participation and security in order to improve the quality of life of older persons" (WHO 2002, p. 12).

2 The World Health Organization (WHO) describes the concept Healthy Aging as "the process of developing and maintaining functional capacity that enables well-being in old age" (WHO 2019, p. 1). 


\section{Case Study}

\subsection{The Emergence of New Tourist Destinations: Cáceres}

Cáceres is a city located in the north of Extremadura and is the capital of the province. It concentrates the largest population of the north of the Autonomous Community, with 96,126 inhabitants (IEEX 2020). Although it may seem small compared to the large Spanish metropolises, like them, it is the leading tourist destination in the area. According to the 2019 Tourism Observatory of Extremadura report, in 2018 it was the city with the most travelers, with a total of 341,524 registered visitors. Throughout the year, tourism almost quadrupled the city's census population. These data explain that the most important economic sector is the service sector, with a total of 30,099 employees (IEEX 2020).

The tourism of the study location is mainly divided into three types: (1) Cultural tourism: among which the Old Town of the city with vestiges of pre-Roman, Almohad, and medieval architecture became a World Heritage Site in 1986. Holy Week was declared a Festival of International Tourist Interest in 2011. The annual organization of the international festival WOMAD (World of Music, Arts, and Dance) founded in 1980 by Peter Gabriel is held in the city; (2) Nature tourism: among the activities and outdoor routes offered to visitors, the festival of the birds of Cáceres ${ }^{3}$ is a highlight, which is attended every year by ornithologists from around the world. The proximity of several protected natural areas, among which the Monfragüe National Park stands out, makes the city a perfect place for this type of tourism; (3) Gastronomic tourism: in addition to having been voted Spanish Capital of Gastronomy in 2015, the city has a restaurant with two Michelin stars (Atrium), which attracts all kinds of visitors.

International and national recognition has not ceased adding to the city's customs, culture, architecture, and even gastronomy. These awards have meant a tremendous increase in the number of companies dedicated to the tourism sector, transforming the city's business vision, which now focuses on satisfying tourist needs (Rengifo et al. 2015). The geographical location of Cáceres—close to the adjacent country, Portugal-makes it an excellent cross-border tourism location. An example of cross-border cooperation is TRIURBIR ${ }^{4}$ (Triángulo Urbano Iberico Rayano), in which two Spanish cities-Cáceres and Plasencia-and two Portuguese cities-Castelo Branco and Portalegre-participate.

Among the active policies to maintain and promote tourism in the region, the Tourism Plan of Extremadura 2017-2020 (Junta de Extremadura 2017) was created. Among its main objectives is the creation of safe and stable employment that follows gender equality, social equity, and quality guidelines and establishes a sustainable economy. The tourism plan is supported by a wide variety of subsidies and grants to improve tourism businesses and achieve stable employment. One example is Decree 31/2017 (DOE 2017), by which the Regional Government of Extremadura grants subsidies to renovate establishments, create new tourist offers, or adapt businesses to new technologies. Other public bodies, such as the Diputación de Cáceres, also carry out programs such as the "Active Tourism Plan" (Diputación Provincial de Cáceres 2019), which aims to help both with the cost of supplies and services and with the creation of marketing campaigns and materials for businesses. Finally, the Chamber of Commerce of Cáceres and the City Council have created an aid package called the “Tourism Competitiveness Programme 2020" (Cámara de Comercio de Cáceres 2020) for investment in actions designed to improve the tourism sector and its adaptation to the new safety regulations derived from COVID-19.

The data from the Observatorio Turístico de Extremadura (2019) show the importance of the tourism sector, with almost 340 establishments destined for tourists (Table 1). In the hotel accommodation category-hotels, hostels, and pensions - the conventional hotel establishments are included. In the extra hotel accommodation category-rural accommodation, tourist apartments,

3 https://festivaldelasavescaceres.juntaex.es/

4 http://www.triurbir.net/ 
lodges, and campsites-the lodgings of lower level establishments are included but these are still registered as hotel services; therefore, this category does not include Airbnb or similar lodgings. Finally, the restaurants category-restaurants, catering, and banquet halls-incorporates the businesses that offer meal services.

Table 1. Number of tourist services in the city of Cáceres according to type (Observatorio Turístico de Extremadura 2019).

\begin{tabular}{ccc}
\hline & Number of Establishments & Number of Places Offered \\
\hline Hotel Accommodation & 34 & 2406 \\
Extra Hotel Accommodation & 111 & 1195 \\
Restaurants & 194 & 17,837 \\
Total & 339 & 21,438 \\
\hline
\end{tabular}

Another essential characteristic of tourist businesses is how they are distributed in the city. Figure 1 shows how the tourist establishments-lodging businesses in blue and restaurants in green-are framed in the tourist area, surrounding the historical heritage of the city. Consequently, this area becomes a stage that is prepared and created for the experience of visitors in all senses (Domínguez-Párraga 2019a; Janoschka 2018; Judd 2002). It should be noted that, as shown in Figure 1, within the tourist zone-red area-there are 76 establishments related to tourism out of a total of 129 that are represented on the map.

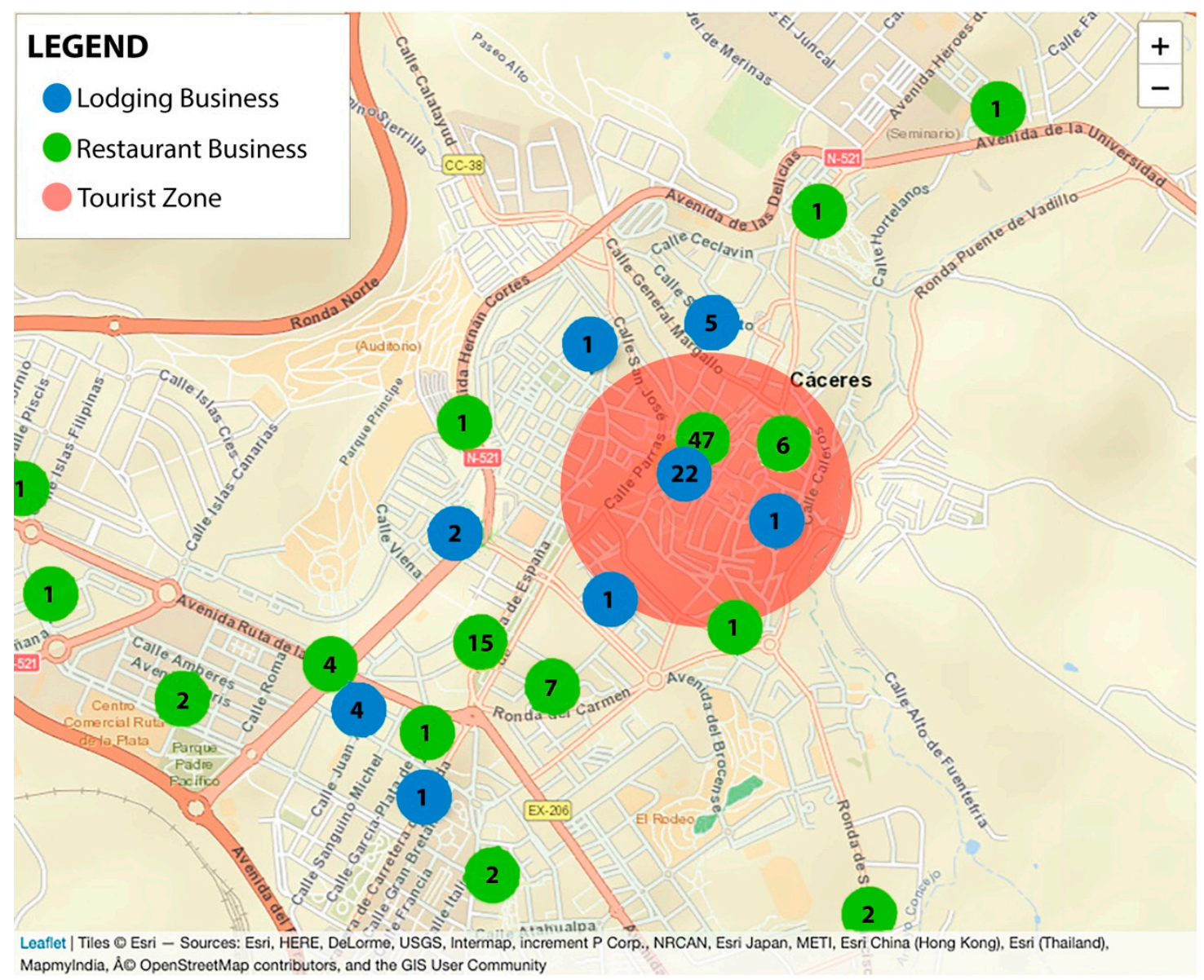

Figure 1. Map of the city of Cáceres, with a number of hotel and restaurant services represented.

Exemplifying the idea of Hiernaux and González (2014), tourism in this area is mainly limited to an enclosure where both urban space and invested capital are allocated to a single objective-to attract 
visitors. Therefore, following the categorization mentioned above in Section 2 (gentrification process) by Janoschka (2018), Cáceres, and, more specifically, the historical center, fulfills the characteristics of gentrification by tourism dispossession, gentrification by commercial and symbolic exclusion, and gentrification everywhere.

\subsection{Neighborhoods Analysis: Gentrification and the Elderly}

The main objective of this research is to analyze how gentrification can affect the daily lives of older people as well as their intention to carry out active aging, taking into account social, symbolic, and spatial variables. Consequently, I start from the hypothesis that elderly residents living in a gentrified neighborhood experience restriction and conditioning of their activities and social and spatial interactions, in comparison to elderly residents of a non-gentrified neighborhood. Given the concentration of tourist activity in a specific area of the city, a comparison was performed between a neighborhood in that area, called Plaza Mayor-gentrified neighborhood (GN) onwards-and another neighborhood outside the tourist area that is non-gentrified, known as Peña del Cura-non-gentrified neighborhood (NGN) onwards. Figure 2 shows the selected neighborhoods: GN in purple and NGN in yellow.

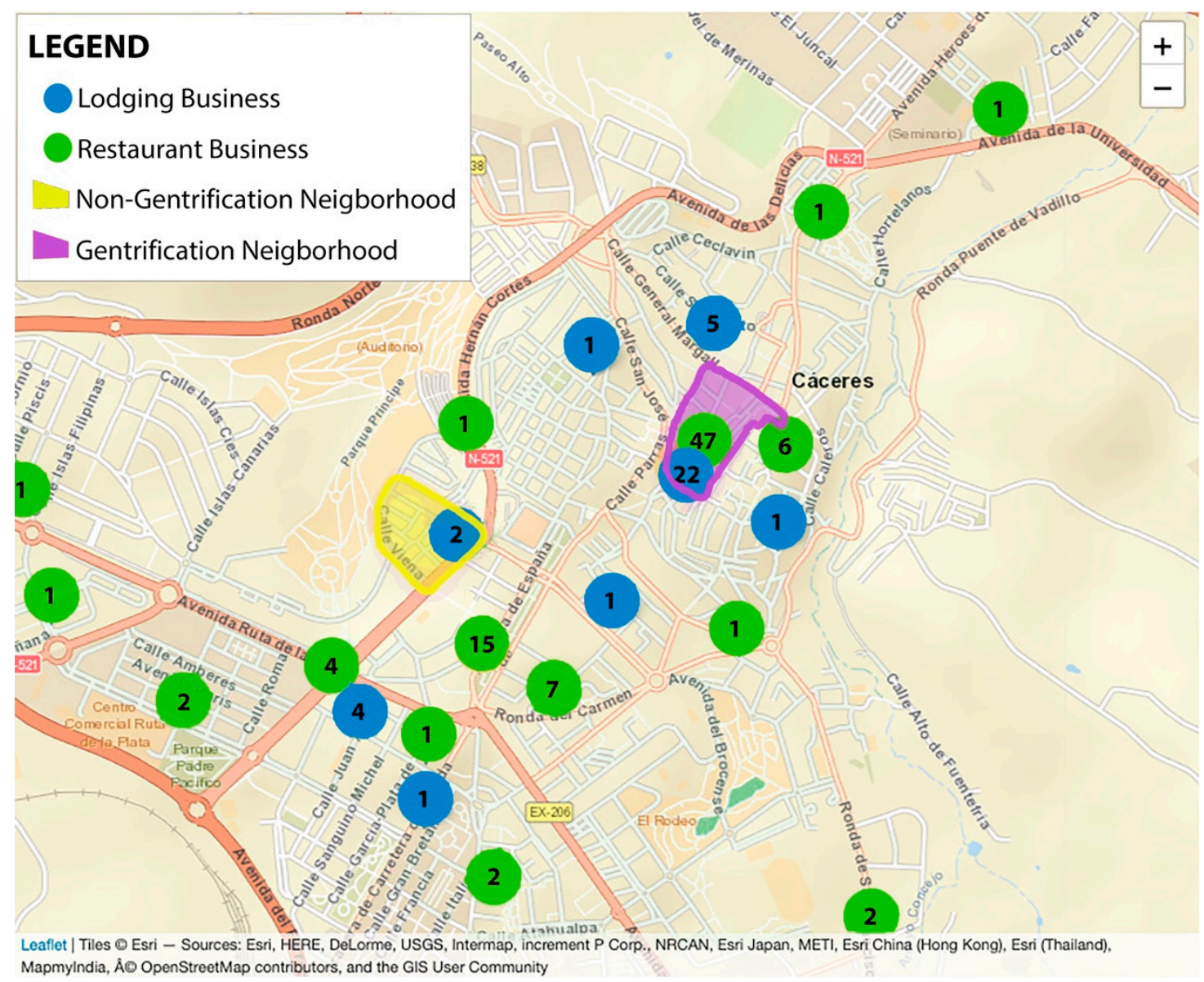

Figure 2. Represention of the gentrified neighborhood (GN) and non-gentrified neighborhood (NGN) and a number of tourist establishments.

Although both neighborhoods are located barely $1 \mathrm{~km}$ apart, some of their differences are evident, such as the number of tourist establishments. Figure 2 shows that in the GN, there are 47 restaurants and 22 lodging businesses. In the NGN, there are merely two restaurants. Such an imbalance is because the GN is located around the Old Town and, therefore, within the tourist area (see Figure 1). In the NGN, there are no signs of tourist gentrification as it has no tourist establishments or establishments 
directly dedicated to this sector, and there are no signs of spatial restructuring or displacement of residents for this reason. Consequently, there is no evidence that any of the criteria for the definition of a gentrified area are met.

\section{Materials and Methods}

In this qualitative study, 32 in-depth interviews were conducted with an average duration of 65 min each. All of the interviewees were 65 years or older, the age at which people are considered to enter old age (Almeida 2014). The sample among neighborhoods was slightly unbalanced; $62.7 \%$ of the interviewees belonged to the NGN and 37.5\% to the GN. Gender differences also existed; $81 \%$ of the sample were women and 50\% were widows at the time of the interview. Gender inequality in the sample was the result of two phenomena; on the one hand, there was a larger population of women than men-especially among older people, since women's life expectancy is longer than men's-and, on the other hand, women tended to be more participatory (Ronzi et al. 2016). Contact with the interviewees was made through two centers where activities aimed at older people were carried out and which were located in the selected neighborhoods. The interviews were carried out in places chosen by the participants to make them feel safe and comfortable.

In qualitative research, these differences between neighborhoods and gender do not represent a significant bias in the analysis of the data. The main reason for selecting participants was their independence, active participation, and residence in the same neighborhood for at least five years. These characteristics were imposed as essential requirements because it is considered that, to study the effect of gentrification on older people, they must maintain interactions with their social and spatial environment continuously over time.

The interview script consisted of six open-ended questions to address those issues that were important to the study. In this way, a fluid conversation was achieved, where the role of the interviewer was to explore all the pre-established items and, at the same time, facilitate the emergence of new ones from the participants themselves and the conversation. The language used for the interviews was Spanish.

Glaser and Strauss (1967) grounded theory was chosen as a qualitative method to analyze the interviews. It is based on the paradigm of symbolic interaction, so individuals and their interactions are located at the research center (Giraldo Prato 2011). Symbolic interactionism focuses on the processes that exist between the interaction or relationship of the actors with their social world. Therefore, this paradigm analyzes the socialization of human beings through which meanings are created and used by their community to relate with one another. Through social interactions, social actors can modify or ratify shared meanings and symbols. Consequently, the grounded theory analyzes the data provided directly by the social agents—-the significants-to explain a social problem-individual and social world interaction. Therefore, taking into account the research hypothesis and objective, it was considered to be a suitable method for this study.

The analysis through the grounded theory is built from data following the inductive method. However, every researcher starts a study with previous knowledge, so the researcher's reflexivity must not distort the analysis of the data and their treatment (McGhee et al. 2007). On the other hand, all research studies must be subject to verification of the methodological process, including those carried out through grounded theory. Nevertheless, these cannot be reproduced since the data generated are unique and unrepeatable (Corbin and Strauss 1990; Luján 2010). Without a doubt, these are some of the limitations that are associated with the use of grounded theory. To ensure the accuracy and robustness of the data and analysis, this research and its methodology were validated by two external and independent researchers with positive results.

The process began with a thorough and careful examination of the transcripts, analyzing each interviewee's words and expressions. From this analysis, significants emerged that helped us understand the individuals' behavior (Hernández Carrera 2014; Vargas Beal 2011). Subsequently, an ascending coding system was established so that the information that emerged from the words—significants-of 
the interviewees could create codes, dimensions, and categories that would allow for qualitative analysis of the data. This analysis was carried out separately for each of the neighborhoods with the Atlas.ti software. This program allows the words or phrases that the researcher considers important to be marked, commented on, and coded from the transcriptions for later analysis. As a result, categories and codes were obtained with different meanings for the residents of the two neighborhoods. An example was the category "commerce," which had pessimistic meanings in the GN but positive ones in the NGN (see Section 5.1).

When analyzing the interviews using the grounded theory, there were four final categories, with their corresponding codes, that provided the most information when comparing the two neighborhoods (Table 2). The categories were related, but when studied separately, the different dimensions of gentrification and its effects on senior residents could be seen.

Table 2. Main categories and research codes.

\begin{tabular}{|c|c|}
\hline Categories & Codes \\
\hline Commerce & $\begin{array}{l}\text { Variety. } \\
\text { Prices. }\end{array}$ \\
\hline Interaction & $\begin{array}{l}\text { Trusted networks. } \\
\text { Inhabited homes. }\end{array}$ \\
\hline Activity & $\begin{array}{l}\text { Dependence on family members. } \\
\text { Place where they carry out the activities. }\end{array}$ \\
\hline Environment & $\begin{array}{l}\text { Perception of the everyday environment. } \\
\text { Perception of the environment as alien. }\end{array}$ \\
\hline
\end{tabular}

\section{Results}

This section contains the analysis of the transcripts, highlighting the most relevant findings. They were grouped into subsections to facilitate the reader's understanding.

\subsection{The Effects of the Neighborhood's Business on Older People}

Several studies show how gentrification processes transform traditional businesses to respond to a new consumer: the tourist or visitor (Guimarães 2019; Petrovic 2008; Janoschka 2018; Romero Renau and Martin 2015). The metamorphosis of the neighborhood's shops and businesses has a series of consequences for its residents. One negative consequence drawn from the analysis of the transcripts was the increase in prices.

When I come from the activity workshop... There is a supermarket there but is very expensive, and the shops are also those that offer a bit of everything. (Woman, 67 years old, GN)

Ah, yes, there is nothing to buy. You have to take the car and go to Mercadona [big supermarket] or Eroski [hypermarket]. There are two or three local shops but come on, to do a shop, a real shopping ... you have to go outside it is the thing we do not have around here. (Woman, 65 years old, GN)

In these two verbatim quotations, taken from two interviews conducted with residents of the GN, two interesting facts were observed. On the one hand, as was to be expected, the shops were expensive, according to the opinions of the neighbors themselves. If we compared the prices between supermarkets in each area-Tambo in the NGN and UNIDE in the GN-the prices of many products varied, with a minimum of 0.10 euros in the GN, compared with the NGN. The most significant disparity was seen in some meat products, an illustrative example being pork ribs, with a price of $4.64 \mathrm{~kg} /$ EUR in Tambo-NGN—versus $6.95 \mathrm{~kg} /$ EUR in UNIDE-GN. Secondly, it was inferred from their words that the variety in terms of products or types of establishment was quite limited, so going to larger commercial areas with more variety became the best option. Consequently, they were forced to buy from shops outside the neighborhood where the products were cheaper and more varied. 
However, when the same category in the NGN interviews was analyzed, it was observed that the residents did not suffer from supply difficulties in the neighborhood, nor did they have problems with product prices. As the second of the fragments below illustrates, they preferred to buy certain types of food in their neighborhood, since the quality of those products was superior to hypermarkets:

... I have everything and more, all kinds of shops ... anyway, if I do not want to leave the neighborhood, I do not leave, I am very good here I am very happy. (Women, 73 years old, NGN)

I always buy fruit, fish, and meat in the neighborhood. I see it like that, in the big supermarkets, I barely buy those kinds of products. Here is my butcher, my fruit seller, and my daughters order me the fruit, it is very good fruit. (Women, 65 years old, NGN)

The responses regarding daily purchases in the GN were negative, and on the contrary, they had a markedly positive character in the NGN. In the GN interviews in which the commerce and purchases of the neighborhood were discussed, $73 \%$ made negative comments or expressed that they would purchase their shopping outside the neighborhood. On the contrary, 59\% of the NGN interviewees conducted their daily shopping in the neighborhood and used positive words to talk about their shops. It could be said that the GN had a low-quality external environment (Gehl 2006), so those mandatory activities, such as daily shopping, were perceived as a negative effort by its inhabitants. This context implied that not only do inhabitants of the GN not enjoy the task, but they also feel the need to carry it out in the shortest time possible.

\subsection{Elderly's Interaction with Their Social Space}

The way individuals perceive their environment can determine how they interact with space. In the case of older people, this interaction can directly impact the individual's physical and emotional health. In the United States, for example, pre-gentrified neighborhoods have high crime rates and violence, so senior residents are afraid and confined to their homes, limiting their social relationships and contacts with the outside world (Petrovic 2008).

In the neighborhoods investigated, the crime rate was close to zero. However, there may also be a hostile perception of the environment. Physical violence is not the only element that makes people feel unsafe. The feeling of loneliness and disconnection from the environment, derived from the lack of social relations, can lead to a decrease in activities. In the GN, the creation of trust networks was more complex, and the feeling of loneliness and insecurity increased:

Well, then a little further down there is a small square with two shops ... a multi-store and a small shop, yes, but in my street, there were two multi-store, and they were removed, and now there are no bars or anything. We had movement when there was a Civil Guard [Police] headquarters, but a few years ago it was closed, and ... very lonely, the truth is that we are very lonely.... No, I do not have any neighbors. So I am telling you, there are times when I miss them, I mean the neighbors ... who help you out... I tell you, I'm there all alone. (Woman, 70 years old, GN)

[...] But I think that there are houses inherited from children to grandchildren and are outside, and they are not interested in doing anything with those houses. So, it would be good that there was someone who cared about those houses because there are many old people, so they are dying, and there are many floors and many empty houses left. (Woman, 67 years old, GN)

This street is very [stresses the "very"] quiet ... I have no neighbors. I have no neighbors! There's one or two ... and nothing. There used to be some [neighbors] there, but they were older, the older ones died, and the young ones left, and it was with them that I had the most relationship. But nothing else. There I have Tomás who has the printing press and another neighbor who doesn't live either... the closest neighbor is Feli. On the way back, I had a very good neighbor, Ana, but she also died, very young. The husband also died, the son is gone... Anyway, no, I have no neighbors. (Women, 71 years old, GN) 
These fragments evoked an image of empty and lonely streets, where there were no shops or people. The houses' owners were becoming older, so they vacated their homes because of either death or obligation. However, this abandonment of the neighborhood did not agreee with the occupation figures, since, as commented before (Figure 2), this area was heavily populated with tourist apartments, hotels, restaurants, and large terraces that filled the neighborhood with people, above all, tourists. In light of the testimonies, it seemed evident that interactions with these temporary residents were nonexistent, as well as relations with the neighborhood services. This situation translated into a somewhat negative perception of the urban environment itself.

In the NGN, the image of the environment evoked through the interviewees' descriptions and words was the opposite. Meanings indicating a full life, security, or familiarity, were repeated several times in the different speeches.

Very quiet, and everyone already knows each other because after so many years, well, I come here [to the bar] and I know that lady, I know this one, I know this one [the bartender], I know everyone because I always come to the same place. (Woman, 76 years old, NGN)

Yes, yes, I know that boy very well because he has been working here in this supermarket for many years. And he took care of me very well, and he still takes care of me very well, because he is there [in another supermarket in the same neighborhood]. ... I am going as if it were my home, you know. (Woman, 72 years old, NGN)

The two previous verbatims give a positive idea of the social relations created and maintained over time in the neighborhood between the neighbors and the shopkeepers. In the two fragments, the interviewees emphasized the importance of time; that is, that these social networks were sustained through years of mutual interaction.

The idea of continuity and time was shown in the interviews as an essential variable when establishing social relationships. In the GN, the lack of interaction with the transitory residents was observed. The repetition of this pattern in the NGN stood out in the analysis, although not with tourists, since they did not exist, but with students who temporarily rented apartments. Therefore, the student was considered a transient resident. If, to this temporal perception, the generational difference was added, the result was a kind of invisible barrier that made the creation of relations and networks of mutual trust highly complex.

Well, look, I have four ... five ... [neighbors] and the rest are all rented to young guys because they are students. So, what you see is that more kids are studying, so we do not have much of a relationship in the community because I am not going to make friends with the students! (Woman, 70 years old, NGN)

In the extract, the difference between neighbors-life-time-and students—-the renters-was observed, with the students not falling into the category of "neighbor." Indeed, the interviewee specified having a friendly relationship with the neighbors but not with the students.

Maintaining healthy social relationships is one of the characteristics of successful aging put forward by the World Health Organization WHO (2002), as social networks have emotional, physical, and psychological benefits. It is vital to interact with the environment and create supportive and trusting relationships in our environment (Buffel et al. 2012). The creation of these networks seems to be based on time. Being surrounded by temporary dwellers, such as tourists, complicates the creation of these significant relationships that are important for everyone, and essential for the elderly.

\subsection{The Importance of Activities for the Elderly: Where and How They Are Carried Out}

In Section 5.1, it was pointed out that there was a lack of shops in the GN. Furthermore, variety was scarce, and prices were high. As a result, most residents were forced to shop outside the neighborhood. This inconvenience was mitigated when the older person could drive; however, this was not the case for 
most older adults. In this circumstance, they needed to depend on other people-mainly relatives-to do their shopping. This dependence on relatives was accentuated for monthly shopping.

Yes, not me, my daughter takes me [in a car] every month when I get paid, she takes me to the ... Mercadona [a supermarket] and I bring everything, you know what I mean. ... Yes, my daughter takes me, and I bring everything, even I bring bread ... I also bring it, I freeze it, and I take it out. Sometimes, I buy some oranges there in Las Claras [a multi-store in the neighborhood], if I need them if I don't need anything, then nothing, and that is it. (Woman, 84 years old, GN)

As the interviewee from the GN stated, the small multi-stores in the neighborhood were only for exceptional purchases, typically, a specific and perishable product that her daughter could not get in the monthly shop. However, what was remarkable about this situation was that it made it impossible to be independent and self-sufficient. The environment limited both pillars of the philosophy of successful aging. Nevertheless, some interviewees were seeking alternatives to reduce their dependence on family members, although they still needed their help:

If there is weight, I tell my son, and if not I have already threatened to say: "Look I'm going to go to Tambo on the first of the month" [supermarket outside the neighborhood] which is where I buy "and I'm going to make the order and have them bring it to me." "Mom, but then you have to go up the stairs and so on," and I tell him, "Well, they can take it up to my house, and that's it." You give a tip, and it is ok, I am here for the moment, but I don't have the strength I used to have, you know? (Woman, 73 years old, GN)

When the neighbor's words from the GN were analyzed, the rebelliousness and eagerness to overcome adversity in the person were recognized. Despite being aware of her limitations derived from her age-over 70 years old - she wanted to remain independent. She preferred to pay more at the local supermarket rather than depend on her son. The analysis showed the need of the elderly to feel independent. Older people's autonomy, dependency, and freedom are fundamental features of successful aging (WHO 2002), but they also have positive health effects. Feeling useful and valid increases self-esteem and prevents illnesses such as depression (Almeida 2014).

More differences existed between neighborhoods regarding everyday activities other than shopping, such as walks, courses, and guided activities. The main difference between the two areas was illustrated by a single question regarding location: Where do most activities occur inside or outside the neighborhood? In the interviews analyzed from the NGN, the neighbors barely left their neighborhood. Some of them forced themselves to move to other areas of the city to carry out some of their daily activities. For example, they walked, which they understood to constitute a healthy exercise:

Because I used to walk a lot around here in Cánovas Avenue, which is very comfortable but you know what happens, you go up "Hello man," you go down "Hi man." And I said no ... I have to take another path. And I took it ... I go straight walking there [new areas of Cáceres] because as it is all flat ... and you don't see people there, at least not familiar people. (Male, 77 years old, NGN)

But now as I go with the girl [her granddaughter] and with the cart, you know what I do, I go along San Pedro Street [pedestrian street outside her neighborhood], I see storefronts, then maybe I go to Antonio Hurtado, and from Antonio Hurtado, I go again to Cánovas Avenue because it's already down [streets outside her neighborhood]. (Woman, 70 years old, GN)

In these fragments, there were several underlying and relevant ideas: on the one hand, the many social interactions that, as seen in the previous section (Section 5.2), occurred in the NGN, up to the point that they prevented the interviewee from carrying out his walk as he wanted. On the other hand, he highlighted the importance of moving to other areas of the city where the orography was flat. The city's Old Town is the main pedestrian area of Cáceres, and it would be expected that people choose it as a pleasant place to go for a walk. However, most of the interviewees, such as the woman's quote explained, preferred other flatter areas, with shops, although they were out of her quarter. 
In the GN, walks outside the area were almost obligatory, as most residents carried out all their activities outside the neighborhood. As shown below, the reactions were varied, while for some people, typically younger and in better health, it was a positive factor, for other older residents, by contrast, it was a negative aspect that required a great deal of effort:

It's a wonder. I leave the house at 8:30 or 8:35 for the gymnastics we start at 9:00. But when I go from my house until there, it's $2 \mathrm{~km}$. When I come back, it's another $2 \mathrm{~km}$. It's already $4 \mathrm{~km}$ more after the exercise you do there [in the gymnastics activity], you know? It's great! (Woman, 67 years old, $\mathrm{GN})$

When I go [to the activity], I go very tired because it is a bit far, and everything is uphill, and when I get there, I go like... [fatigued]. (Woman, 84 years old, GN)

When faced with a similar situation, the age difference between the interviewees-67 and 84 years-revealed opposite attitudes. The first woman perceived traveling to the place of the activity as something positive since it helped her to exercise more and, therefore, take care of herself better. At 67, she can be considered a relatively young woman in her old age. For the second 84-year-old interviewee, making the trip twice a week because of the course schedule required a lot of determination. She did not perceive the trip as an opportunity, but quite the contrary. Nonetheless, she continued to attend her classes as she was aware of the importance of getting out of the house and interacting with other people. In both cases, one can see how important it is for active seniors to take care of themselves, physically, cognitively, and emotionally, although they must make an extra effort to achieve it (Domínguez-Párraga 2019b).

Most residents of the GN perceived it as natural to perform daily activities in other parts of the city. The $69 \%$ of NGN interviewees who carried out any guided activity claimed to do it within the neighborhood itself, compared to $18 \%$ of GN residents. They assumed it was normal because they did not feel part of their environment. In the NGN, where, according to those interviewed, they had everything available to them, they only went to other parts of the city for specific things or with clear objectives. Moreover, for some of the NGN residents, moving to do activities in the GN was too far away for them to make the trip regularly, as they were accustomed to attending the nursing home in the area, which was just a few meters away from their house.

-[Interviewed] I've thought about going to the Athenaeum [a cultural association], playing the Athenaeum, but I'm a little lazy. This [nursing home where she has her classes] is next door.

-[Interviewer] And the Athenaeum, where is it?

-[Interviewed] On the side of the main square [in the GN]. It's very far away. (Woman, 80 years old, NGN)

In the interviews analyzed from the GN, none of the participants reported the idea of remoteness or laziness in carrying out daily activities outside the quarter. Therefore, the perception of having everything within reach, as was the case in the NGN, had the result that the symbolic construction of its environment, the image of its neighborhood (Lynch 1960), was limited mainly to that area, excluding the rest of the city.

\subsection{The Perception of the Neighborhood: The Use Made of the Environment}

Following Kevin Lynch (1960) idea of the image of the city, through the interactions we have with the environment, we will create one image or another. The form in which we perceive the city as a result of the activities we carry out means that we perceive distinct areas of the same city in different ways. Previously, in Section 5.3, I observed how covering the same distance-the one that separates the GN from the NGN-was not understood in the same way by the neighbors of one area as by those 
of the other. Consequently, the image we create of our environment is determined by the relationship we have with it, and this, in turn, influences the form of the socio-urban interaction.

Upon analysis of the transcriptions, it was noticed that the interviewees' images of the entire Old Town and the center of Cáceres were of an environment that was not part of the city. It was more like a set, an open-air theatre where people went for festivities and special events. Fainstein and Judd (1999) referred to these kinds of cities built, or rather re-built, to attract tourism, as "cities as places to play." In Cáceres, this term would apply only to the Old Town of the city (GN), reducing the activities in this area to three classes: religious, cultural, and tourist.

\subsubsection{Religious Activity}

According to data collected by the Centro de Investigaciones Sociológicas (CIS 2020) in March 2020, more than 50\% of Spain's population considers itself to be Catholic, yet only $19.5 \%$ are practicing Catholics, i.e., they attend Mass. Of this percentage, $40.7 \%$ are people over 65 . Our sample was not an exception, and $65 \%$ of the participants defined themselves as practicing Catholics. Therefore, activities related to religion should be considered as everyday activities.

In Cáceres, coinciding with Holy Week, the procession of the descent of the patron saint of the city_Virgen de la Montaña (Virgin of the Mountain)—is held. The divine image is deposited during the novena (nine days) in the Concatedral of Santa María, located in the Old Town of the city. During these days, the parishioners come to see the Virgin. It is one of the reasons that the NGN interviewees claimed to go to the GN during the year. Even though the environment was unfavorable, due to the orography, their faith encouraged them to go:

I'm going to the Plaza Mayor [GN], I'm going to see the Virgin of the Mountain come down. I go for a couple of days. It's hard for me, I have to sit on benches because I can't do everything at once, but I'm going to see the Virgin of the Mountain, yes. (Woman, 75 years old, NGN)

The woman made an effort for a religious event. In fact, throughout the interview, she pointed out that she did not usually go to this neighborhood.

\subsubsection{Cultural Activities}

The Cáceres Old Town is one of the areas that host the highest number of cultural activities throughout the year. Among the events are the classical theatre festival, the summer open-air cinema, the Medieval Market of the Three Cultures. These cultural activities, most of which are free, bring many local and foreign people together in the GN of the city. These events also attract NGN interviewees, and it is only at these specific times of the year that they come to this area.

Yes, but well, we go to the park in the morning, and we always move around this circle, but then in summer, I go to the classical theatre. When they play films in the forum of the Balbos, I also go. If they do something special in the old quarter, I also go. (Man, 71 years old; NGN)

In the previous verbatim, it followed that he did not usually leave his neighborhood. His motivation to go to the GN and leave his routine and comfort zone lay in the realization of new or different activities. Therefore, there was no doubt that they related going to the GN with special occasions rather than with everyday life.

\subsubsection{Tourist Activities}

As the Old Town and the GN are gentrified areas, activities related to tourism are intrinsically linked. Thus, in the transcripts, it was observed that for many interviewees from the NGN quarter, going to the GN quarter was a compulsory task every time family or friends visited them, that is to say, it was mandatory to visit the tourist part of Cáceres. One of the interviewees explained it: 
I really like the old part a lot. Whenever someone comes, usually not by myself, I don't go either, but when someone from family or friends comes, I always, always bring them to the old part, always! It is obligatory! (Woman, 73 years old, NGN)

The transcript showed that she did not go to that part of the city normally or voluntarily, limiting her itinerary to that area to when family and friends were visiting.

In the analysis of the interviews, it was observed that the GN was not a component of the city's image for the residents of the NGN. For these residents, the GN was limited to a set of restricted activities and special occasions. At the same time, the interviewees who lived in the GN carried out most of their daily activities outside it. Therefore, they did not have a close or trusting relationship with the environment of their neighborhood; however, this type of relationship with their environment was the case with the older people of the NGN.

\section{Conclusions}

In the literature, it is common to find quantitative approaches and those circumscribed to large cities. (Atkinson 2000; Henig 1984; Petrovic 2008), for example, focused on the effects of gentrification through comparison between generations. The literature does not usually study how this phenomenon affects older residents. Hence, this paper used a qualitative approach to compare the effects of the gentrification process on older people between different areas of a medium-sized city.

An in-depth analysis was performed involving 32 interviews with older people inhabiting two nearby neighborhoods with different gentrification degrees in the city of Cáceres, Spain. The selected subjects met the criteria of active aging, as described by the WHO (2002).

The main findings of this approach revealed how the interactions with the environment of the senior residents of the gentrified neighborhood were truncated and limited, forcing them to conduct activities related to their daily life outside the neighborhood. These neighbors were forced to travel to other parts of the city to perform basic tasks, making them less pleasant and more emotionally and physically costly. They were forced to break their bonds of trust with their social environment and limit interaction with their spatial surroundings. As a consequence, they created an unfavorable internal image of the neighborhood in which they live. Furthermore, not feeling part of a community or within the safety of a group had adverse effects on people and how they perceived the environment in which they live. The gentrified neighborhood transmitted an idea more similar to a ghost or abandoned neighborhood than a friendly and lively one.

On the other hand, the non-gentrified neighborhood participants drew a much more positive image of their environment, where the social relations established with the neighbors and traders of the area stood out. This positive image was mainly due to the fact that daily activities were carried out within the neighborhood, and only voluntarily and on specific occasions did they decide to leave it.

Therefore, the consequences of the gentrification process affect older people in a very profound way. The problem goes beyond the generalized increase in prices or the lack of diversity in establishment typology. The feeling of not being part of their neighborhood by being separated from it, symbolically and physically, leads to feelings of abandonment, loneliness, and insecurity.

A coexistence between the economic interests derived from tourism and the welfare of a location's inhabitants should be possible. Perhaps one approach to achieve this would be to follow the example of the age-friendly cities (WHO 2007). In this case, the implementation of improvements in cities, taking into account the needs of the elderly, has created new market niches and business opportunities (Organisation for Economic Co-Operation and Development 2014). By transferring this approach to tourism and involving the main social actors in decision-making, positive effects can be achieved both in terms of the city's economy and the quality of life of its residents.

Funding: This research received no external funding.

Acknowledgments: I would like to thank the 32 participants in the study for their selfless collaboration.

Conflicts of Interest: The author declares no conflict of interest. 


\section{References}

Almeida, Maria. 2014. A identidade na velhice. In Envelhecimento, Saúde e Cidadania. Edited by Maria Almeida and João Luís Alves Apóstolo. Coimbra: UICISA, pp. 13-37.

Atkinson, Rowland. 2000. Measuring gentrification and displacement in Greater London. Urban Studies 37: 149-65. [CrossRef]

Bounds, Michael, and Allan Morris. 2006. Second wave gentrification in inner-city Sydney. Cities 2: 99-108. [CrossRef]

Brusilovsky, Berta L. 2016. Innovaciones en accesibilidad cognitiva. Entornos urbanos que hablan a las personas. Colección democratizando la ciudad, La ciudad Accesible. vol. 11. Available online: http://riberdis.cedd.net/ handle/11181/4974 (accessed on 18 December 2019).

Buffel, Tine, Chris Phillipson, and Thomas Scharf. 2012. Ageing in urban environments: Developing 'age-friendly' cities. Critical Social Policy 32: 597-617. [CrossRef]

Cámara de Comercio de Cáceres. 2020. Programa de Competitividad Turística 2020. Available online: https: //www.camaracaceres.com/competitividad-turistica-2020/ (accessed on 15 August 2020).

Centro de Investigaciones Sociológicas (CIS). 2020. Barómetro de Marzo (muestra total). Estudio n³277. Available online: http://www.cis.es/cis/opencm/ES/1_encuestas/estudios/listaMuestras.jsp?estudio=14493 (accessed on 5 July 2020).

Corbin, Juliet M., and Anselm Strauss. 1990. Grounded theory research: Procedures, canons, and evaluative criteria. Qualitative Sociology 13: 3-21. [CrossRef]

DOE. 2017. Decreto 31/2017. Diario Oficial de Extremadura, Spain, March 27. Available online: http://doe.gobex. es/pdfs/doe/2017/590o/17040036.pdf (accessed on 15 August 2020).

Diputación Provincial de Cáceres. 2019. BOP-2019-1603 Convocatoria Normas Reguladoras Plan Activa Turismo 2019. April 16. Available online: https://bop.dip-caceres.es/bop/services/anuncios/contenidoPdfIdAnuncio?c sv=BOP-2019-1603 (accessed on 15 August 2020).

Domínguez-Párraga, Lidia G. 2019a. Neighborhood Influence: A Qualitative Study in Cáceres, an Aspiring Age-Friendly City. Social Sciences 6: 195. [CrossRef]

Domínguez-Párraga, Lidia G. 2019b. Percepción de la salud y el cuidado personal de los mayores: un caso de estudio en Cáceres, España. En Investigación en salud y envejecimiento: Volumen VI. Almería: Asociación Universitaria de Educación y Psicología (ASUNIVEP), pp. 547-54.

Fainstein, Susan S., and Dennis R. Judd., eds. 1999. Cities as places to play. In The Tourist City. New Haven: Yale University Press, pp. 261-72.

Gehl, Jan. 2006. La humanización del Espacio Urbano. La vida social entre edificios. Madrid: Editorial Reverté.

Giraldo Prato, Marisela. 2011. Abordaje de la investigación cualitativa a través de la teoría fundamentada en los datos. Ingeniería Industrial. Actualidad y Nuevas Tendencias 6: 79-86. Available online: https://www.redalyc.or g/pdf/2150/215021914006.pdf (accessed on 25 January 2020).

Glaser, Barney G., and Anselm L. Strauss. 1967. The Discovery of Grounded Theory: Strategies for Qualitative Research. Chicago: Aldine.

Glass, Ruth. 1964. London: Aspects of Change. London: MacGibbon \& Kee, vol. 3.

Guimarães, Pedro. 2019. Exploring the Impacts of Gentrified Traditional Retail Markets in Lisbon in Local Neighbourhoods. Social Sciences 6: 190. [CrossRef]

Harvey, David. 2004. El "nuevo" imperialismo. Acumulación por desposesión. Socialist Register 42: 99-129.

Harvey, David. 2008. El derecho a la ciudad. New Left Review 53: 23-39. Available online: http://newleftreview.es/53 (accessed on 14 September 2019).

Henig, Jeffrey. R. 1984. Gentrification and displacement of the elderly: An empirical analyses. In Gentrification, Displacement, and Neighborhood Revitalization. Edited by J. John Palen and Bruce London. Albany: State University of New York Press, pp. 170-84.

Hernández Carrera, Rafael. 2014. La investigación cualitativa a través de entrevistas: Su análisis mediantela teoría fundamentada. Cuestiones Pedagógicas 23: 187-210.

Hiernaux, Daniel, and Carmen I. González. 2014. Turismo y gentrificación: Pistas teóricas sobre una articulación. Revista de Geografía Norte Grande 58: 55-70. [CrossRef] 
Instituto de Estadística de Extremadura (IEEX). 2020. Datos Padrón, resultados detallados, municipios de Cáceres (2019). Available online: https://ciudadano.gobex.es/web/ieex/tablas/-/tabla/ficha/9781529. (accessed on 5 April 2020).

Instituto Nacional de Estadística (INE). 2019. Cuenta Satélite del Turismo de España (CSTE). Revisión estadística 2019, serie 2016-2018. Available online: https://www.ine.es/prensa/cst_2018.pdf. (accessed on 25 January 2020).

Janoschka, Michael. 2018. Gentrificación en España "reloaded". Papers: Gentrificació i dret a la ciutat 60: 24-33.

Janoschka, Michael, Jorge Sequera, and Luis Salinas. 2014. Gentrification in Spain and Latin America-A Critical Dialogue. International Journal of Urban and Regional Research 4: 1234-265. [CrossRef]

Judd, Dennis R., ed. 2002. The Infrastructure of Play: Building the Tourist City. Armonk: ME Sharpe.

Junta de Extremadura. 2017. Plan Turístico de Extremadura 2017-2020. Available online: https://www.turismoextre madura.com/viajar/shared/documentacion/publicaciones/PlanTuristicoExtremadura2017_2020.pdf (accessed on 17 August 2020).

Lefebvre, Henri. 1968. Le droit à la ville. Paris: Anthropos, vol. 3.

Luján, Noemí. 2010. Lo cualitativo como estrategia de investigación: Apuntes y reflexiones. In El arte de investigar. Edited by Pablo Mejía, José Manuel Juárez and Sonia Comboni. México: Mc Editores, pp. 213-31.

Lynch, Kevin. 1960. The Image of the City. Cambridge: MIT Press, vol. 11.

McGhee, Gerry, Glenn R. Marland, and Jacqueline Atkinson. 2007. Grounded theory research: Literature reviewing and reflexivity. Journal of Advanced Nursing 60: 334-42. [CrossRef] [PubMed]

Observatorio Turístico de Extremadura. 2019. Memoria turística de Extremadura por territorios, año 2018. Mérida: Junta de Extremadura, Available online: https:/www.turismoextremadura.com/.content/observatorio/2019/ EstudiosYMemoriasAnuales/Memoria_turistica_por_territorios_2018.pdf (accessed on 7 September 2020).

Organisation for Economic Co-Operation and Development. 2014. The Silver Economy as a Pathway for Growth. Insights from the OECD-GCOA Expert Consultation 26 June 2014. Available online: https: //www.oecd.org/sti/the-silver-economy-as-a-pathway-to-growth.pdf (accessed on 17 August 2020).

Petrovic, Ana. 2008. The elderly facing gentrification: Neglect, invisibility, entrapment, and loss. Elder Law Journal 15: 533

Rengifo, Juan Ignacio, Antonio José Campesino, and José Manuel Sánchez. 2015. El turismo en la ciudad de Cáceres (1986-2010): un cuarto de siglo emblemático. Asociación de geógrafos españoles 67: 375-401. Available online: https://www.age-geografia.es/ojs/index.php/bage/article/viewFile/1830/1746. (accessed on 2 October 2019).

Ronzi, Sara, Daniel Pope, Lois Orton, and Nigel Bruce. 2016. Using photovoice methods to explore older people's perceptions of respect and social inclusion in cities: Opportunities, challenges and solutions. SSM-Population Health 2: 732-45. [CrossRef] [PubMed]

Romero Renau, Luis Del, and Laura Lara Martin. 2015. De barrio-problema a barrio de moda: Gentrificación comercial en Russafa, el "Soho" valenciano. Anales de geografía de la Universidad Complutense 35: 187-212. [CrossRef]

UN-Habitat. 2018. Leading Change: Delivering the New Urban Agenda through Urban and Territorial Planning. Kuala Lumpur: UN-Habitat, Available online: https://unhabitat.org/sites/default/files/download-manager-files/Lea ding\%20Change_Web\%20Version\%2001.02.18.pdf (accessed on 17 August 2020).

Vargas Beal, Xavier. 2011. ¿Cómo hacer investigación cualitativa? Una guía práctica para saber qué es la investigación en general y cómo hacerla, con énfasis en las etapas de la investigación cualitativa. Jualisco: ETXETA.

World Health Organization (WHO). 2002. Active Ageing: A Police Framework. Geneva: WHO, Available online: https://www.tandfonline.com/doi/abs/10.1080/tam.5.1.1.37 (accessed on 20 January 2020).

World Health Organization (WHO). 2007. Global Age-Friendly Cities: A Guide. Geneva: WHO.

World Health Organization (WHO). 2019. Década del envejecimiento saludable. Geneva: WHO. Available online: https://www.who.int/docs/default-source/documents/decade-of-health-ageing/decade-healthy-ageing-up date1-es.pdf?sfvrsn=d9c40733_0. (accessed on 15 August 2020).

Zukin, Sharon. 1990. Socio-spatial prototypes of a new organization of consumption: The role of real cultural capital. Sociology 24: 37-56. [CrossRef]

(C) 2020 by the author. Licensee MDPI, Basel, Switzerland. This article is an open access article distributed under the terms and conditions of the Creative Commons Attribution (CC BY) license (http://creativecommons.org/licenses/by/4.0/). 